\title{
Identity and digital equity: Reflections on a university educational technology course
}

\author{
Katherine McLay, Vicente Chua Reyes Jr \\ The University of Queensland
}

\begin{abstract}
This inquiry explored preservice teachers (PSTs) developing learner and professional identities while participating in a university course that explicitly incorporates the use of technology into teaching. The paper posits that it is important for initial teacher education to explicitly engage with the role of technology in these developing identities to minimise the risk of digital inequity, both for PSTs' learning and that of their future students. Two central questions are addressed: How did PSTs make sense of their identities as they took part in an educational technology course? And what challenges did they encounter in incorporating technology into their learning experiences? An exploratory case study of a group of tutors and participating students in an ongoing action research project directed at redesigned educational technology and innovation course at a higher education institution was undertaken for this inquiry. By critically interrogating students' reflexive accounts and focus group discussions with academics teaching into the course, this inquiry has investigated and built emerging explanations in relation to identity and digital equity.
\end{abstract}

Implications for practice or policy:

- Positive learner and professional identities are associated with better outcomes.

- PSTs develop learner and professional identities in ways that are intertwined with their attitudes towards and experiences with technology.

- $\quad$ PSTs with negative digital learner-teacher identities may first experience digital inequity at university and subsequently contribute to digital inequity in their own future students - double jeopardy digital inequity.

- Initial teacher education should explicitly cultivate positive digital learner-teacher identities in preservice teachers.

Keywords: learner identity, digital equity, digital exclusion, preservice teacher education, university

\section{Introduction}

There is broad scholarly agreement that students with a positive learner identity tend to achieve stronger academic outcomes and have more positive learning experiences. In the context of preservice teacher (PST) education, learner identity is intertwined with developing professional identity: PSTs who develop a sense of themselves as capable teachers become more effective practitioners because of the strong link between identity and practice (Wenger, 1998). Building on this foundational stance, this paper argues that in the contemporary Australian educational context, tertiary institutions must deliberately cultivate in PSTs positive and productive technology-related identities in relation to their capacity to integrate technology meaningfully into teaching and learning to "expand curriculum learning opportunities for students" (Australian Institute for Teaching and School Leadership [AITSL], 2011, p. 11). We deploy the term technology-related throughout this paper to convey the relational connectedness between technology and PSTs' sense of who they are as learners and future teachers. We argue that, without this careful attention to the identity issues that emerge from teaching and learning about technology, double jeopardy digital inequity may arise: PSTs who do not have positive learner identities associated with technology use may not develop a sense of themselves as capable teachers in relation to information communication technologies (ICTs). As a result, the PST's own future school students may not experience ICT-supported learning that develops the technological knowledge, skills and attitudes critical for twenty-first century life and work.

There is a significant body of scholarly work that conceives learning as a complex and interrelated set of academic and non-academic processes, including identity development. The relationship between learner identity, effective approaches to learning, and learning outcomes is similarly well established. A learner's 
sense of self in relation to personal and social factors - including but not limited to age, race, socioeconomic background and gender - can profoundly affect learning outcomes in the present as well as imagined possible future life and learning trajectories. In technology-rich educational contexts, learners' facility with, access to and attitudes towards digital tools is entangled with these various personal and social factors, adding another dimension to learner identities and, of interest in this paper, to developing PST professional identities. PST professional identities emerge alongside and are enmeshed with their sense of themselves as learners because teacher education involves (professional learning (learning about teaching and learning) and intra-personal learning (learning about oneself as a teacher and learner) (Jones, 2009). As Dall'Alba and Barnacle (2007) (see also Dall'Alba \& Barnacle, 2005, 2009; Dall'Alba \& Bengtsen, 2019) and others have contended for some time, a narrow focus on intellect (epistemology) in tertiary education fails to account for the new ways of being (ontology) that develop alongside knowledge and skills. PSTs are thus not just developing the how and what of teaching but also ways of "thinking, making and acting" (Dall'Alba \& Barnacle, 2007, p. 682) - identities - including in relation to technology.

Our interest in this field developed though praxis as we co-taught a first-year educational technology course that we had redesigned. We noticed that many of the approximately 300 students enrolled in this course each year - mainly school leavers or so-called "digital natives" (Prensky, 2001) - expressed anxiety about and resistance to using digital tools for teaching and learning. When we began to interrogate the data generated for this research, our impression that the PSTs in the course felt this way was supported not only by our own reflexive practice but also in the lived experience of other academics teaching into the course and in the students' reflections, captured in assessment artefacts. Like many other scholars, we were and remain sceptical of highly contested and arguably empirically unfounded claims that today's students are sophisticated and intuitive native users of technology (e.g., Bennett, Maton, \& Kervin, 2008; Helsper \& Eynon, 2010; Henderson, Selwyn, \& Aston, 2017; Kennedy, Judd, Dalgarno, \& Waycott, 2010). Even so, when confronted with the reality of our students' anxiety and resistance, we were surprised - an interesting point of reflection for us as academics in this field. As we began to dig into existing scholarship, we found points of alignment. For example, Forkosh-Baruch (2018) argued that despite being expected to incorporate technology meaningfully into learning experiences, contemporary PSTs "may not be technologically knowledgeable or exhibit ICT skills as anticipated; they may prove to be poorly prepared to utilize ICT as students and as future teachers" (p. 416; see also Kumar \& Vigil 2011; Lei, 2009).

In this paper, we argue that PST attitudes towards technology for teaching and learning play a role in shaping their developing learner identities - a sense of who they are as learners at university - and their developing professional identities as teachers - a sense of the kind of teacher they will be in the future. The term technology-related captures this relational connectedness between technology and PST's sense of who they are as learners and future teachers. We argue that PST technology-related learner and developing professional identities influence both their capacity and their inclination to integrate technology into teaching and learning. This raises equity issues, both for PSTs and their future school students - double jeopardy digital inequity. PSTs who already have positive technology-related learner identities are more likely to experience success in technology-rich learning settings and more likely to deploy technology in ways that open up learning opportunities for their own students.

Integrating technology into classroom practice is a fundamental expectation in the contemporary Australian and global educational landscape. The capacity to use technology to "expand learning opportunities for students" is embedded in the AITSL (2011, p. 11). ICT capability comprises one of the seven general capabilities in the Australian Curriculum, and ICTs for teaching and learning are embedded in every learning area. Given that (a) there is vast scholarship supporting the contention that positive learner identity is interconnected with effective approaches to learning and learning outcomes; (b) research indicates that PST's sense of themselves as capable teachers contributes to their effectiveness as teachers; and (c) integrating ICTs into teaching and learning is an expected practice, we contend that PST education must take account of and deliberately cultivate positive digital learner and professional identities. This is critical both for PSTs' own learning and practice, as well for their own future students who face the technological ubiquity of twenty-first century work and life. 
To unpack our contention, we were guided by two research questions:

(1) How did PSTs make sense of their identities as they took part in our redesigned educational technology course?

(2) What challenges did PSTs encounter in incorporating technology into their learning experiences?

First, we provide a broad overview of the literature in relation to learner identity. While a comprehensive review of this body of work is beyond the scope of this paper, we locate our own perspectives in relation to the broader landscape by foregrounding some of the ways that learner identity generally and technologyrelated learner identity specifically have been explored. We also explore evolving scholarly understandings of the so-called "digital divide" from early conceptions of access and lack of access to the more nuanced terms digital inclusion and digital exclusion. These terms grapple with the equity issues that arise from the complex interplay of economic, technological and social factors, the latter of which includes developing learner identities. Building on these foundations, our own reflections as co-designers and co-teachers of a first-year educational technology course are intertwined with focus group discussions with academics teaching into the course and interrogation of participant students' critical self-reflections on the course experience, captured in assessment task artefacts. Drawing on these data, we consider the implications for initial teacher education and argue that cultivating positive learner identities for PSTs in relation to technology teaching and learning is critical to avoid double jeopardy digital inequity: first, for PSTs' own experience of learning and developing professionalism in relation to technology; and second, for the learning of their future school students.

\section{Learner and learning identity(ies)}

Over the past four decades, research into classroom practice has made it clear that academic activities such as reading and writing occur at the same time as and are not easily distinguishable from "social identification, power relations, interpersonal struggles and other apparently non-academic processes" (Wortham, 2006, p. 1). While there are different approaches to understanding the relationship between the academic and non-academic, a sociocultural stance conceives these as a complex interrelationship in which academic learning and social identification "overlap and partly constitute" one another (Wortham, 2006, p. 1). As such, an individual's perception of him or herself - sense of identity - in a learning situation impacts significantly on learning and construction of knowledge (Williams \& Burden, 1997).

Despite agreement within the social sciences that identity is a critical element of human learning, it is a concept that resists a precise and universal meaning (Radovic, Black, Williams, \& Salas, 2018), and scholars define it in a range of ways. For example as a story of the self that gives "unity, purpose and meaning" to life (McAdams \& Olson, 2010, p. 527); as a sense of self (Helms, 1998); as a society of Ipositions (Konopka, Hermans, \& Goncalves, 2018); as lived relations within a community of practice (Lave \& Wenger, 1991); and as being recognised by self or others as a certain "kind of person" (Gee, 2001, 2005). Luehmann (2007) argued that there are some commonalities to these varied approaches, reflecting a view of learning as an active and socially situated process:

- Identity is socially constituted, that is, one is recognized by self and others as a kind of person because of the interactions one has with others.

- Identity is constantly being formed and reformed, though the change process for one's core identities is long term and labor intensive.

- Identity is considered by most to be multifarious, that is, consisting of a number of interrelated ways one is recognized as a certain kind of person, participating in social communities.

- Identity is constituted in interpretations and narrations of experiences. (p. 827, emphasis in original)

In addition to an understanding that academic development and selfhood or becoming are intertwined, there are also equity and social justice implications for learner identity. The relationship between learner identity and academic engagement and achievement has been explored in a variety of contexts across all levels of education. In relation to school students, for example, the concept of mathematical identity/ies - defined as "socially produced ways[s] of being, enacted and recognised in relation to mathematics learning" (Darragh \& Radovic, 2018, p. 2) - has been deployed to consider why some students have difficulty with the subject 
or how identity markers such as race or gender have a negative impact on engagement (Radovic et al., 2018). Similarly, research into science education has argued that changes to science pedagogy and content are needed so that girls can develop learner identities as "people who can do and learn science" (Carlone, 2004, p. 392). In addition to gender, socioeconomic background, race and ethnicity have all been found to play a role in students' engagement with science education (Archer et al., 2010). In short, there is a substantial body of work indicating that "students' sense of self-identity is a major factor in how they respond to school subjects" (Archer et al., 2010, p. 617). In the tertiary context, there is similar scholarship supporting the connection between academic outcomes and approaches to learning and broader social and psychological factors. For example, Reay, Crozier, and Clayton (2010) focused on the interplay between learner identity and socioeconomic background. Bliuc, Ellis, Goodyear, and Hendres (2011) found that students' social identities - a sense of self derived from identifying with particular social groups - has an impact on the ways students approach learning and subsequent academic performance. Another area of interest in the tertiary sector is how the transition to university can disrupt previously secure learner identities - an "intensely emotional" experience "that can affect students' self belief and feelings of competence" (Christie, Tett, Cree, \& McCune, 2016, p. 479).

In sum, learners of all ages, in all contexts and across all learning areas with a positive sense of who they are as learners are more likely to approach learning effectively and achieve better academic outcomes. In the following sections, focus shifts from these broad understandings of the relationship between various aspects of learner identity and learning outcomes to consider PSTs specifically and the role played by technology in their learner identities and developing professional identities.

\section{PSTs and the enmeshment of learner and professional identities}

Scholarly interest in the ways that PSTs develop professional identities reflects an understanding that becoming a teacher involves developing a new identity (Danielwicz, 2001; Goodson \& Cole, 1994; Williams, 2014), which includes values, attitudes and beliefs about learners, education and a philosophy of teaching. For example, Luehmann (2007) built on the work of Gee (2001) who, like Lasky (2005), defined teacher identity as "being recognised by self or others as a certain kind of teacher" (p. 827). This goes beyond practice and includes "professional philosophy, passions, commitments, ways of acting and interacting, values, and morals" (Luehmann, 2007, p. 828). For PSTs, learner identity and professional identity are enmeshed and co-constitute one another because teacher education involves learning about teaching and learning, as well as learning about oneself as a teacher and learner (Jones, 2009). Teacher identity begins to form during initial teacher education and continues throughout the PST's career (ForkoshBaruch, 2018). Supporting PSTs to develop identities both as learners and teachers can help them make sense of the seeming disjuncture between coursework and practical experience (Ma \& Singer-Gabella, 2011). In the context of research into preservice English teachers, Park (2013) argued that learning involves not only acquiring knowledge and skills but also "identity work in which learners see themselves as becoming participants in a field or community" (p. 363). All these understandings reflect the view of learning as an active and socially situated process, outlined earlier, and also recently foregrounded by Izadinia (2018).

Izadinia (2018) found that internal factors (e.g., motivation and prior experience) and external factors (e.g., university and school mentor teachers, peers, family background) contribute to a PST's developing learnerteacher identity. Indeed, modelling by teacher educators is a vital element of PST identity development (Lee \& Jo, 2016). Others see PST identity development as connected to literacy practices, because "the identities that we construct shape our literacy practices, while our practice helps determine a means for acting out the identities we assume" (Wise \& O’Byrne, 2015, pp. 400-401; see also McCarthey \& Moje, 2002; Park, 2013). The enmeshment of identity with literacy practices is interesting when considering technology-related identity work, taken up in the next section. For PSTs, it is increasingly appreciated that integrating technology into teaching and learning requires a "positive digital professional identity" (Forkosh-Baruch, 2018, p. 417).

\section{Learner identities in a digital world}

There has been international preoccupation, over the past two decades, with preparing students for a digital future (e.g., Daggett, 2010, Organisation for Economic Co-operation and Development [OECD], 2016; 
Ribble, 2015). Incorporating the digital into teaching and learning is no longer just accepted, but expected (Erstad, 2012; OECD, 2015), resulting in widespread and rapid uptake of digital tools in education (Henderson \& Yeow, 2012; Major, Haßler, \& Hennessy, 2017). In Australia, for example, the digital education revolution - a key element of the Australian Labor Party's 2007 federal election campaign aimed to provide all Australian secondary school students with laptop computers (Commonwealth of Australia, 2009). The ubiquity of technology in schools and universities has opened up a new area of interest for scholars interested in learner identity. For example, the fluidity afforded by mobile digital devices has brought the entwinement of social and academic into the spotlight through the increasing visibility of unstructured forms of and spaces for informal learning such as social media (Sangra, Raffaghelli, \& GuitertCatasus, 2019). Since the smartphone first emerged in the early 1990s, ICTs have increasingly been deployed as learning tools in a variety of formal and informal contexts beyond the space-time boundaries of school or university (Greenhow \& Robelia, 2009). This has led to the hybridization of learning, "both in terms of the medium (digital, on-site) and the type of learning (formal, non-formal, informal)" (Sangrá, Raffaghelli, \& Guitert-Catasús, 2019, p. 1621, emphasis in original). This new educational context has been explored by scholars in many ways, including how blended and online approaches to teaching and learning have led to students developing competing or contradictory online and offline identities (Bullingham \& Vasconcelos, 2013). The ways that learning is increasingly unbounded and occurs across schooled and nonschooled real and virtual sites is of increasing interest for educational researchers, with many exploring the "rich and complex learning ecology within which children build a variety of experiences, competencies and interests" (Rajala, Kumpulainen, Hilppö, Paananen, \& Lipponen, 2016, p. 15; see also Sefton-Green \& Erstad, 2013, 2017).

The concept of learning ecology describes "the accessed set of contexts, comprised of configurations of activities, material resources and relationships, found in co-located physical or virtual spaces that provide opportunities for learning" (Barron, 2004, p. 6). A learner's ecology is composed of diverse physical and virtual settings as well as human and technological experiences and relationships both at and beyond school (Lai \& Gu, 2011). Barron's (2004) relatively early but important research demonstrates how technological fluency - which others might call literacy or capital - is achieved across contexts (e.g., private, social, professional, school, university) and through various resources (hardware, software, human, material), activities and relationships (human, both with self and others, and non-human). The potential for inequity as a result of the richness or otherwise of an individual's learning ecology seems obvious, and the evolving use of the term digital divide reflects increasingly nuanced understandings of technology-related equity issues.

In the mid-1990s, the term digital divide was used to describe concerns around unequal access to ICTs (Mossberger, Tolbert, \& Stansbury, 2003) and the consequent disadvantage to people without adequate access to technology and/or Internet connectivity (e.g., Anderson, 2015). Over time, however, this first digital divide was criticised for its simplistic "dichotomies of haves and have-nots" (Helsper, 2012, p. 403; see also Helsper \& Reisdorf, 2017). The 'second digital divide' (Attewell, 2001) shifted from access to a more multidimensional approach that took disparities in computer and Internet use into account. This perspective is reflected in the OECD (2001) definition of the digital divide as "the gap between individuals, households, businesses and geographic areas at different socio-economic levels with regard both to their opportunities to access information and communication technologies (ICTs) and to their use of the Internet for a wide variety of activities" (p. 5). However, Ragnedda (2017) contended that this definition still does not consider "either the influence that pre-existing socio-economic inequalities have on digital inequalities, or, conversely, how digital inequalities influence the social structure" (p. 14). The third digital divide therefore reflects researchers' evolving understanding that there is no single, simple gap, but rather a "constellation of social, economic and technological issues" (p. 15) - much like a learning ecology. All these diverse, multifaceted and interwoven social, economic, technological issues, experiences and relationships contribute to learners' developing sense of who they are - their learner identities - which are brought to formal, non-formal and informal learning across a range of real and virtual contexts and impact on learners' approaches to learning, learning outcomes, and future personal and professional trajectories:

Differences in accessing and using ICTs, and specifically the Internet, are not merely technologically or economically contingent, but are also based on different cultural, social, personal and political capital. That is, such differences not only mirror the social strata, but also produce different outcomes (in terms of knowledge and life chances) that reinforce the pre-existing social strata. (Ragnedda, 2017, p. 15) 
To bring this all together, there is a well-developed body of work that underscores the relationship between learner identity and learning outcomes generally, as well as in relation to digital learner identity specifically, including blended, online, formal and informal learning contexts. Further, there is longstanding scholarly agreement that the rise of ICTs - especially the Internet - has advantaged those users with "more information skills, more resources, and more social and economic capital" (Ragnedda, 2017, p. 15) leading to new forms of inequality and social segmentation and reinforcing those which already exist. There is a strong correlation between successful learning outcomes and positive learner identities, which are influenced by a constellation of issues including gender, race, socioeconomic background, and other forms of personal and cultural capital such as technological facility as well as values, attitudes and beliefs about technology. With this background in mind, we turn to an overview of the first-year educational technology course we co-taught, then demonstrate how our reflexive engagement with this experience, alongside other data sources, highlight the importance of cultivating positive technology-related learner identities in PSTs.

\section{Background and context of the educational technology course}

In 2017, we were tasked with redesigning a large, compulsory first-year course that focused on educational technology and innovation. To do this, we leveraged the university's interest in developing active learning approaches (The University of Queensland, 2017-2018) to increase student engagement and satisfaction. For this innovation, we adopted five design principles:

- Flipped learning: Face-to-face lectures were replaced with online lectures in three out of every four weeks.

- Tutors as critical friends: Rather than focusing on teaching how to use specific digital tools, tutors worked alongside students as they explored technology during the Sandpit tutorials (discussed shortly) to identify problems, find solutions, and explore possibilities.

- Sandpit-Synergy - Showcase: Tutorials followed this three-wave structure, culminating in the Showcase tutorial where the groups presented their final, digital product.

- Group assessment: For three of the four assessment tasks, students worked in the same, selforganised communities of practice (Wenger, 1998).

- Critical reflection: This was formally captured in the individual, final task but also embedded in the Synergy wave of the tutorials.

These design principles were used as the scaffold to underpin the four core competencies that we aimed to develop in our students: 21st century skills of curating (Bearden, 2016; Robertson, 2012), collaborating, creating and critically reflecting (Germaine, Richards, Koeller, \& Schubert-Irastorza, 2016) on ICT and its application to teaching and learning. Students in the 2017 and 2018 iterations of the course were organised into tutorial groups of approximately 20 students each. Tutors who taught into the re-designed course were conceived as critical friends and facilitated four waves of a three-step workshop format built around active learning principles: (a) Sandpit - PSTs "play" and plan a curriculum-based group output; (b) Synergy PSTs undertake a dry run of the classroom-based output and receive feedback from their peers and tutor; and (c) Showcase - PSTs present the final output, refined in response to feedback.

The four waves of the three-step workshop format centred on the challenge of letting the groups of PSTs prepare a curriculum output with the use of specific ICT platforms that were integrated with the targeted core competencies. The first wave used Pinterest as a curating tool, the second deployed Prezi as a collaborative instrument, and for the third students used Powtoon as a creative platform. For each task, students were required to collaboratively decide on the year level, learning area and one or two specific content descriptions from the Australian Curriculum their digital output would target. The fourth piece of assessment was an individual task. PSTs could choose any ICT platform to create a digital narrative which critically reflected on their experience in the course.

\section{Method}

This paper reports on a targeted reflexive case study (Huiru, 2009) which draws on data generated in a larger, ongoing action research project. As a method, case study is widely deployed in social research (Alvesson \& Sköldberg, 2009) to generate insights into contemporary phenomena (e.g., events, problems, 
situations). Case study is adaptable to different kinds of evidence (Huiru, 2009), such as the studentproduced artefacts and reflexive accounts of practice we draw on in this paper. The reflexive case study method opens up possibilities for less conventional approaches because it applies practice theory to both data-generation (in our case, students' critically reflective digital artefacts and tutors' reflexive accounts) and to analysis of that data (Rittenhofer, 2015).

The data we draw on for this case study was generated in the first (2017) and second (2018) iterations of the course under scrutiny. In addition to the imperative of generating and reporting on data in relation to the overarching action research project, we were experiencing some more immediate institutional pressure to determine whether this course, which we had been asked to redesign in an effort to improve student satisfaction, had indeed achieved this goal. It was against the backdrop of this institutional pressure that we noticed PST anxiety about and resistance to using technology for teaching and learning. As we discovered, through informal conversations and team meetings with academics teaching into the program, that this anxiety and resistance appeared to be common across all tutorial groups, our curiosity was piqued, and this research is the result. This reflexive case study is targeted because it focuses on our desire to understand the identity issues that arise as PSTs engage with ICT for teaching and learning. As described earlier, learning involves PSTs' in developing identities as they) learn about teaching and learning and learn about themselves as a teacher and learner (Jones, 2009).

Two central questions guided our targeted case study:

(1) How did PSTs make sense of their identities as they took part in our redesigned educational technology course?

(2) What challenges did PSTs encounter in incorporating technology into their learning experiences?

\section{Participants}

The participants in this case study are the nine academics who taught into the course in 2017 (including the authors) and students enrolled in the 2018 iteration of the course. All 248 first-year PSTs enrolled in 2018 were invited to participate in this research project. In those instances where specific outputs produced by the PSTs were used for data analysis (discussed in the following section), explicit consent was sought and provided. In all, 21 students (aged between 18 and 19 years old), consisting of eight males and 12 females, from the entire cohort consented to their reflexive accounts being used for this case study. Ethical clearance was obtained through the overarching action research project, which was part of a university-wide initiative to increase student satisfaction and engagement using active learning approaches.

\section{Data}

The data sources are:

(1) Reflective focus group discussions with nine academics teaching into the course: Three months after the conclusion of the 2017 iteration of the course, the nine academics teaching into the course (including the authors) wrote a 500-word narrative detailing our experience as a course tutor, anchored by the question, What are my personal experiences as a tutor in implementing a new course that attempted to incorporate technology into teaching and learning? The narratives were uploaded to Dropbox. We then met for three 2-hour meetings. During these meetings, we read our narratives aloud and discussed and reflected on one another's experiences. The conversations were organic. No one formally led the meetings; rather, we freely explored, shared, reflected, asked questions and commented on our similar and different experiences. As we interacted and our experiences and stories became entangled (Davies \& Gannon, 2012), some common themes became apparent. These themes were recorded in minutes kept by the first author, while all participants contributed comments to the narratives on Dropbox.

(2) Participant students' critical self-reflections on the course experience: Students' reflexive accounts of their experiences in the course were captured in individually developed digital stories using students' preferred software (e.g., Powtoon, PowerPoint, iMovie, Prezi). The digital story was the final assessment task in the 2018 iteration of the course. Students were not explicitly asked to reflect on their identity. The task required students to critically reflect on their 
learning in the course by considering, for example, issues and challenges associated with integrating technology into teaching and learning and their own experiences learning with ICT. Students could also reflect on their learning experiences beyond the course.

Together, these data provide rich, reflexive accounts of academics' and PSTs' experiences teaching and learning with technology. Our interest in how technology plays into PSTs developing learner and professional identities and how these technology-related learner and professional identities could result in what we call double jeopardy digital inequity developed through reflexive engagement with these data sources. The experiential accounts of tutors and PSTs illustrate how teaching and learning with technology does not simply involve introducing a neutral tool into the process, but requires teachers and learners to become different kinds of teachers and learners; that is, to take up new ways of being teachers and learners both in the present and in imagined possible futures. In the following sections, we illustrate how this complex and tension-filled experience raises the possibility of double-jeopardy digital inequity.

\section{Data analysis}

In undertaking this case study, we adopted a reflexive approach to generating and analysing qualitative data, designed to enable "researchers to be reflexive about how they analyse other people's accounts of their lives" (Mauthner \& Doucet, 2003, p. 414). As the individuals who co-taught, we were motivated to understand and appreciate how our PST learners experienced the course. Moreover, this prefatory investigation is a work in progress of a continued and engaged discussion of digital technology, our shared experiences of the course and ongoing trends that occur in ICT. We subscribe to Berger's (2015) working definition where she argues that "[R]eflexivity is commonly viewed as the process of a continual internal dialogue and critical self-evaluation of researcher's positionality as well as active acknowledgement and explicit recognition that this position may affect the research process and outcome" (p. 220). Thus, as we interrogate the data that we obtained for this inquiry, we are conscious of our shifting positionality: as facilitators of skills and knowledge of ICT use in teaching for our PSTs, as well as reflexive practitioners intent on developing insights into issues and challenges encountered by our PSTs in their learning journey.

For this case study, we identified data that captures the ways in which PSTs' developing learner and professional identities are related to and intertwined with technology. In terms of the three 2-hour reflective focus group discussions with the academics teaching into the course, two of the themes that emerged in situ as we reflected on and discussed our experiences (Larrivee, 2000) are relevant here:

(1) Competing or shifting identities: During the Sandpit sessions, tutors found their role shifted constantly and fluidly between being a learner of ICT and a teacher of ICT. Often, as they worked alongside students as critical friends, tutors needed to exercise judgement about when to take on a more traditional teacher role to help a student who was floundering or frustrated. Similarly, tutors observed students taking up teacher identities both in small group and whole class contexts, coaching their peers and the tutor in some aspect of the technology they had mastered. Other students simply did not see themselves as technologically adept, and therefore could not imagine using the technologies the course engaged with as teachers in the future. However, for many students, this sense of themselves now and into the future shifted over time as the course progressed.

(2) Discomfort: All tutors experienced discomfort as they engaged with new or unfamiliar technologies, expressing anxiety around their own lack of expertise and the need to be resilient to mistakes and overcome problems - both so the lesson was successful and so they were modelling these skills for students. Tutors also observed their students experiencing discomfort in a range of ways. Some students yearned for a more traditional and didactic course structure with a weekly lecture and tutorial rather than a flipped approach, while others would have preferred to write an essay than develop digital artefacts.

In terms of the students' digital artefacts, we first reviewed the corpus of data (i.e., digital artefacts produced by the 21 students who consented their use in this research) to identify statements or utterances that related to identity. In total, 27 utterances were identified. Of these, 11 were made by female PSTs and 16 by male PSTs. We then engaged in a reflexive discussion and analysis of these utterances to identify key learnings that could be gleaned about students' sense of themselves as learners and future teachers and patterns 
between the students' reflexive digital artefacts and the tutors' reflections on their experiences teaching into the course.

\section{Analysis and discussion}

From the reflexive analysis of the data outlined above, we offer two insights: first, that tutors play a powerful role in influencing and shaping PSTs' developing learner and professional identities, and second, that discomfort is a common experience for tutors and students.

\section{The role of tutors}

The key role played by course tutors in transforming PST identity as both learners and future practitioners emerged strongly in both data sets. In particular, students appear to particularly value the ways that tutors make connections between coursework and classroom practice. These connections appear to be made in two key ways: first, by actually using the various technologies during tutorials, reflective of Lee and Jo's (2016) assertion that modelling by university teachers is critical for PST learning and development; and second, by making explicit connections to how the technology could be used with school students through demonstrations, practical examples, and sharing stories from the tutor's own teaching experience. In these ways, we suggest that tutors open up new imagined possible ways of deploying technology for teaching and learning in PSTs' future classrooms. Tutors are not simply showing PSTs how to use various technologies; rather, they are supporting PSTs to develop a professional identity as capable future teachers of and with technology. By integrating digital tools and then actively making connections to practice, PSTs can imagine themselves doing the same in the future. Of the 27 utterances related to identity, nine reflected a shift in their sense of their future professional identity in relation to technology during the course. For example:

Over the weeks I was transformed from a sceptic of the use of ICT in the classroom to being an appreciator of it and in fact a future user of it. (Female student)

When I first entered [course name], I was convinced the technology could not and did not correlate with my discipline areas. I have changed those views. (Male student)

I have gained insight into the power of technology in the classroom. (Female student)

Previously, during my school experience, I thought the best way to learn was to listen and read. (Male student)

These examples capture PSTs in moments of professional identity transformation as they imagine the place of technology in their future trajectories as practitioners, shifting from sceptical to appreciative, changing views about technology in the classroom and gaining insights into its potential and power. Further, the theory-practice divide is a dominant theme in teacher education research, and while practicing schoolteachers are seen as participating in the lived reality of classroom life, teacher educators tend to be regarded as "aloof within the ivory tower, espousing ideals and the principles that govern them" (Smagorinsky, Cook, \& Johnson, 2003, p. 1400). It is possible that the cyclical Sandpit - Synergy Showcase approach to group assessment, combined with tutors deliberately taking on the role of critical friend and co-explorer rather than expert, offers one way of bridging this persistent divide. Such role modelling may contribute to PSTs having positive learning experiences as students and help to cultivate positive digital professional identities. In so doing, PSTs become more likely to imagine a future trajectory in which they use technology meaningfully in their own classrooms, thereby impacting positively on their own future students' technology-related learning experiences.

\section{Embracing discomfort to avoid double jeopardy digital inequity}

As we reflected upon the experiences of PSTs and tutors who were involved in this course, one of the recurring reflexive points that emerged was the notion of discomfort, particularly in relation to the explicit use of technology in teaching and learning activities. We are aware of Tsikriktsis's (2004) definition of ICT discomfort as "a perceived lack of control over technology and a feeling of being overwhelmed by it" ( $p$. 44). We are also cognisant of the work of Niess (2005), who investigated discomfort experienced by PSTs 
as they attempted to integrate technology into the teaching of mathematics and science subjects. However, as we continually reflect on the lessons learned from the course, what we encounter is the need to embrace discomfort as necessary, both to integrate technology into teaching and learning and to develop new ways of being learners and teachers in relation to technology. In the data generated by participant students' digital artefacts, 10 of the 27 utterances related to identity engaged with the notion of discomfort in relation to technology. For example:

[Technology] can be a frustrating and less effective learning tool. (Male student)

Many teachers are unlikely to use technology in their classrooms, likely due to it being outside their comfort zone. (Male student)

In the discussions that the teaching team undertook while reflecting on the course, the tutors also expressed discomfort as they grappled with new ICTs so they could support their students. As we continually reflect on these tensions and struggles, we have become convinced of the need to clearly foreground how technology integration into teaching and learning will undoubtedly cause discomfort for PSTs, practitioners and initial teacher educators. We suggest that a vital phenomenon that higher education institutions as well as schools must squarely address is negotiating challenges that arise as teachers and learners grapple with discomfort in relation to technology.

One of the main claims of this inquiry is that failing to develop positive learner identities in our PSTs might lead to double jeopardy digital inequity. One PST reflected that "previously, due to my school experience, I thought the best way to learn was to listen and read" (male student). We argue that at the beginning of the course, this PST, like a number of his peers, already experienced some form of digital inequity; that is, their lack of positive exposure to technology gave them a view of learning confined to, for example, "listening and reading". Further, we contend that this paucity of learner identity experiences with technology - albeit filled with bouts of discomfort - risks a second wave of digital inequity. As the participant student above noted, "many teachers are unlikely to use technology in their classrooms, likely due to it being outside their comfort zone" (male student). This leads to the ultimate digital inequity: that experienced by school students whose teachers feel incapable, ill-equipped or disinclined to deploy technology to expand learning opportunities for the young people in their care.

\section{Concluding remarks and insights}

Our interest in the relationship between technology and PSTs' learning and professional identities germinated during our experience co-teaching a first-year educational technology course. This paper captures our first engagement with the data with the specific aim of interrogating PSTs' developing learner and professional identities in relation to technology. This research focus was stimulated by reflexive practice and professional conversation around some of the tensions and challenges we observed while teaching the course. One obvious limitation of our study is that we are at the beginning of our research journey into what we call double jeopardy digital inequity. This phenomenon became visible to us through reflexive practice and engagement with data generated as part of a larger action research project. Nuances such as gender, race, socioeconomic background and connections between students' developing learner and professional identities and their learning outcomes need to be explored. For example, while we have identified the number of male and female participant students for methodological transparency, we have not interrogated how gendered dynamics may impact on PSTs developing technology-related digital identities in this inquiry. Our data sample is also small and confined to one course at one institution. However, these limitations reflect rich possibilities for future research across a range of methodological approaches. There is literature exploring university students' learner identities both generally and in relation to technology, and scholarly engagement with preservice teachers' professional identity development, including their attitudes towards technology and the value of PSTs having "positive digital professional identity" (Forkosh-Baruch, 2018, p. 417). However, we believe this paper offers a novel conceptual contribution by explicitly considering how PSTs' digital learner and professional identities may impact on their experience in initial teacher education in the first instance and subsequently on the learning experiences of their own future students.

While the PSTs in our course are overwhelmingly school leavers, they are not necessarily technologically confident or inclined to use technology in the classroom. Nevertheless, as graduates, our students are 
expected to be able to "implement teaching strategies for using ICT to expand curriculum learning opportunities for students" (AITSL, 2011, p. 11) as well as support school students to develop the ICTrelated outcomes identified in each of the learning areas in the Australian Curriculum. This is no small feat, especially on an uneven playing field - PSTs have diverse learning ecologies and learner identities, not all of which support effective approaches to technology-related learning. This paper posits that initial teacher education should actively support PSTs to develop learning ecologies that enhance PST learning experiences and outcomes in relation to technology and support PSTs to develop positive digital professional identities, making it more likely that they will, in turn, deploy technology to enhance their own students' learning. Together with deliberate course design, the role modelling of tertiary educators including a capacity to embrace discomfort - can support PSTs to develop a sense of themselves as competent learners and teachers of and with technology. As a result, PSTs are more likely to incorporate ICTs into their practice for the benefit of their own students.

\section{Acknowledgements}

The authors would like to acknowledge the contribution of Lauren Thomasse to the ongoing coding and interrogation of the data upon which we draw in this paper. This research has been supported by The University of Queensland through the project Strengthening the gateways: Building pathways to success through active learning / Active Learning Pathways Project (2017-2018) (grant no. 2017001085).

\section{References}

Alvesson, M., \& Sköldberg, K. (2009). Reflexive methodology: New vistas for qualitative research (2nd ed.). London, United Kingdom: Sage.

Anderson, N. (2015). Digital technologies and equity: Gender, digital divide and rurality. In M. Henderson \& G. Romeo (Eds.), Teaching and digital technologies: Big issues and critical questions (pp. 46-56). Melbourne, Australia: Cambridge University Press.

Archer, L., DeWitt, J., Osborne, J., Dillon, J., Willis, B., \& Wong, B. (2010). “Doing” science versus "being" a scientist: Examining 10/11-year-old schoolchildren's constructions of science through the lens of identity. Science Education, 94(4), 617-639. https://doi.org/10.1002/sce.20399

Attewell, P. (2001). Comment: The first and second digital divides. Sociology of Education, 74(3), 252259. https://doi: $10.2307 / 2673277$

Australian Institute for Teaching and School Leadership. (2011). Australian professional standards for teachers. Carlton South, Australia: Education Services Australia.

Barron, B. (2004). Learning ecologies for technological fluency: Gender and experience differences. Journal of Educational Computing Research, 31(1), 1-36. https://doi.org/10.2190/1N20VV12-4RB5-33VA

Bearden, S. M. (2016). Digital citizenship: A community-based approach. Singapore: Corwin Press.

Bennett, S., Maton, K., \& Kervin, L. (2008). The 'digital natives' debate: A critical review of the evidence. British Journal of Educational Technology, 39(5), 775-786. https://doi.org/10.1111/j.14678535.2007.00793.x

Berger, R. (2015). Now I see it, now I don't: Researcher's position and reflexivity in qualitative research. Qualitative Rresearch, 15(2), 219-234. https://doi.org/10.1177/1468794112468475

Bliuc, A. M., Ellis, R. A., Goodyear, P., \& Hendres, D. M. (2011). Understanding student learning in context: Relationships between university students' social identity, approaches to learning, and academic performance. European Journal of Psychology of Education, 26(3), 417-433. https://doi.org/10.1007/s10212-011-0065-6

Bullingham, L., \& Vasconcelos, A. C. (2013). 'The presentation of self in the online world': Goffman and the study of online identities. Journal of Information Science, 39(1), 101-112. https://doi.org/10.1177/0165551512470051

Carlone, H. B. (2004). The cultural production of science in reform-based physics: Girls' access, participation, and resistance. Journal of Research in Science Teaching, 41(4), 392-414. https://doi.org/10.1002/tea.20006

Christie, H., Tett, L., Cree, V. E., \& McCune, V. (2016). 'It all just clicked': A longitudinal perspective on transitions within university. Studies in Higher Education, 41(3), 478-490, https://doi.org/10.1080/03075079.2014.942271 
Commonwealth of Australia. (2009). Overview. Retrieved from http://www.deewr.gov.au/SCHOOLING/DIGITALEDUCATIONREVOLUTION /Pages/default.aspx

Daggett, W. R. (2010). Preparing students for their technological future. Rexford, NY: International Center for Leadership in Education. Retrieved from http://www.leadered.com/pdf/Preparing $\% 20$ Students $\% 20$ for $\% 20$ Tech $\% 20$ Future $\% 20$ white $\% 20$ paper. $\underline{\mathrm{pdf}}$

Dall'Alba, G. (2009). Learning professional ways of being: Ambiguities of becoming. Educational Philosophy and Theory, 41(1), 34-45. https://doi.org/10.1111/j.1469-5812.2008.00475.x

Dall'Alba, G., \& Barnacle, R. (2005). Embodied knowing in online environments. Educational Philosophy and Theory, 37(5), 719-744. https://doi.org/10.1111/j.1469-5812.2005.00153.x

Dall'Alba, G., \& Barnacle, R. (2007). An ontological turn for higher education. Studies in Higher Education, 32(6), 679-691. https://doi.org/10.1080/03075070701685130

Dall'Alba, G., \& Bengtsen, S. (2019). Re-imagining active learning: Delving into darkness. Educational Philosophy and Theory, 51(14), 1-13. https://doi.org/10.1080/00131857.2018.1561367

Danielewicz, J. 2001. Teaching selves: Identity, pedagogy, and teacher education, Albany, NY: State University of New York Press.

Darragh, L., \& Radovic, D. (2018). Mathematics learner identity. In S. Lerman (Ed.), Encyclopedia of mathematics education (pp. 1-4). Cham, Switzerland: Springer. https://doi.org/10.1007/978-3-31977487-9 100017-1

Davies, B., \& Gannon, S. (2012). Collective biography as pedagogical practice: Being in becoming in relation to place. In M. Somerville, B. Davies, K. Power, S. Gannon, \& P. de Carteret (Eds.), Place pedagogy change (pp. 129-142). Rotterdam, The Netherlands: Sense.

Erstad, O. (2012). The learning lives of digital youth: Beyond the formal and informal. Oxford Review of Education, 38(1), 25-43. https://doi.org/10.1080/03054985.2011.577940

Forkosh-Baruch, A. (2018). Preparing preservice teachers to transform education with information and communication technologies. In J. Voogt, G. Knezek, R. Christensen, \& K. W. Lai (Eds.), Second handbook of information technology in primary and secondary education (pp. 415-432). Cham, Switzerland: Springer. Retrieved from https://link.springer.com/content/pdf/10.1007/978-3-31971054-9 28.pdf

Gee, J. P. (2001). Identity as an analytic lens for research in education. Review of Research in Education, 25(1), 99-125. https://doi.org/10.3102/0091732X025001099

Gee, J. P. (2005). An introduction to discourse analysis: Theory and method (2nd ed.). New York, NY: Routledge.

Germaine, R., Richards, J., Koeller, M., \& Schubert-Irastorza, C. (2016). Purposeful use of 21st century skills in higher education. Journal of Research in Innovative Teaching, 9(1), 19-29. Retrieved from https://assets.nu.edu/assets/resources/pageResources/journal-of-research-in-innovative-teachingvolume-9.pdf\#page $=27$

Goodson, I. F., \& Cole, A. L. (1994). Exploring the teacher's professional knowledge: Constructing identity and community. Teacher Education Quarterly, 21(1), 85-105. Retrieved from www.jstor.org/stable/23475536

Helms, J. V. (1998). Science- and me: Subject matter and identity in secondary school science teachers. Journal of Research in Science Teaching, 35(7), 811-834. https://doi.org/10.1002/(SICI)10982736(199809)35:7<811::AID-TEA9>3.0.CO;2-O

Helsper, E. J. (2012). A corresponding fields model for the links between social and digital exclusion. Communication Theory, 22(4), 403-426. https://doi.org/10.1111/j.1468-2885.2012.01416.x

Helsper, E. J., \& Eynon, R. (2010). Digital natives: Where is the evidence? British Educational Research Journal, 36(3), 503-520. https://doi.org/10.1080/01411920902989227

Helsper, E. J., \& Reisdorf, B. C. (2017). The emergence of a "digital underclass" in Great Britain and Sweden: Changing reasons for digital exclusion. New Media \& Society, 19(8), 1253-1270. https://doi.org/10.1177/1461444816634676

Henderson, M., Selwyn, N., \& Aston, R. (2017). What works and why? Student perceptions of 'useful' digital technology in university teaching and learning. Studies in Higher Education, 42(8), 1567 1579. https://doi.org/10.1080/03075079.2015.1007946

Kennedy, G., Judd, T., Dalgarno, B., \& Waycott, J. (2010). Beyond natives and immigrants: Exploring types of net generation students. Journal of Computer Assisted Learning, 26(5), 332-343. https://doi.org/10.1111/j.1365-2729.2010.00371.x 
Henderson, S., \& Yeow, J. (2012). IPad in education: A case study of iPad adoption and use in a primary school. In Proceedings of the 45th Hawaii International Conference on System Sciences (pp. 78-87). Piscataway, NJ: IEEE. https://doi.org/10.1109/HICSS.2012.390

Huiru, Y. (2009). A case study: Innovation of internal teaching and learning evaluation system in higher education institutions. Chinese Education and Society, 42(1), 95-104. https://doi.org/10.2753/CED1061-1932420108

Izadinia, M. (2018). Mentor teachers: Contributions to the development of preservice teachers' identity. In P. A. Schutz, J. Hong, \& D. Cross Francis (Eds.), Research on teacher identity: Mapping challenges and innovations (pp. 109-119). Cham, Switzerland: Springer.

Jones, M. (2009). Transformational learners: Transformational teachers. Australian Journal of Teacher Education (Online), 34(2), 15. https://doi.org/10.14221/ajte.2009v34n2.2

Konopka, A., Hermans, H. J., \& Gonçalves, M. M. (2019). The dialogical self as a landscape of mind populated by a society of I-positions. In A. Konopka, H. J. Hermans, \& M. Goncalves (Eds.), Handbook of dialogical self theory and psychotherapy: Bridging psychotherapeutic and cultural traditions (Chapter 2). New York, NY: Routledge.

Kumar, S., \& Vigil, K. (2011). The net generation as preservice teachers. Journal of Digital Learning in Teacher Education, 27(4), 144-153. https://doi.org/10.1080/21532974.2011.10784671

Lai, C., \& Gu, M. (2011). Self-regulated out-of-class language learning with technology. Computer Assisted Language Learning, 24(4), 317-335. https://doi.org/10.1080/09588221.2011.568417

Larrivee, B. (2000). Transforming teaching practice: Becoming the critically reflective teacher. Reflective Practice, 1(3), 293-307. https://doi.org/10.1080/713693162

Lasky, S. (2005). A sociocultural approach to understanding teacher identity, agency and professional vulnerability in a context of secondary school reform. Teaching and Teacher Education, 21(8), 899916. https://doi.org/10.1016/j.tate.2005.06.003

Lave, J., \& Wenger, E. (1991). Situated learning: Legitimate peripheral participation. Cambridge, United Kingdom: Cambridge University Press.

Lee, O., \& Jo, K. (2016). Preservice classroom teachers' identity development in learning to teach physical education. The Asia-Pacific Education Researcher, 25(4), 627-635. https://doi.org/10.1007/s40299-016-0290-5

Lei, J. (2009). Digital natives as preservice teachers: What technology preparation is needed? Journal of Computing in Teacher Education 25(3), 87-89. https://doi.org/10.1080/10402454.2009.10784615

Luehmann, A. L. (2007). Identity development as a lens to science teacher preparation. Science Education, 91(5), 822-839. https://doi.org/10.1002/sce.20209

Ma, J. Y., \& Singer-Gabella, M. (2011). Learning to teach in the figured world of reform mathematics: Negotiating new models of identity. Journal of Teacher Education, 62(1), 8-22. https://doi.org/10.1177/0022487110378851

Major, L., Haßler, B., \& Hennessy, S. (2017). Tablet use in schools: Impact, affordances and considerations. In A. Marcus-Quinn \& T. Hourigan (Eds.), Handbook on digital learning for K-12 schools (pp. 115-128). Cham, Switzerland: Springer.

Mauthner, N. S., \& Doucet, A. (2003). Reflexive accounts and accounts of reflexivity in qualitative data analysis. Sociology, 37(3), 413-431. https://doi.org/10.1177/00380385030373002

McAdams, D. P., \& Olson, B. D. (2010). Personality development: Continuity and change over the life course. Annual Review of Psychology, 61, 517-542. https://doi.org/10.1146/annurev.psych.093008.100507

McCarthey, S. J., \& Moje, E. B. (2002). Identity matters. Reading Research Quarterly, 37, 228-238. https://doi.org/10.1598/RRQ.37.2.6

Mossberger, K., Tolbert, C. J., \& Stansbury, M. (2003). Virtual inequality: Beyond the digital divide. Washington, DC: Georgetown University Press.

Niess, M. L. (2005). Preparing teachers to teach science and mathematics with technology: Developing a technology pedagogical content knowledge. Teaching and Teacher Education, 21(5), 509-523. https://doi.org/10.1016/j.tate.2005.03.006

Organisation for Economic Co-operation and Development. (2001). Understanding the digital divide (OECD Digital Economy Papers, No. 49). Paris, France: Author. https://doi.org/10.1787/236405667766

Organisation for Economic Co-operation and Development. (2015). Students, computers and learning: Making the connection. Paris, France: Author. https://doi.org/10.1787/9789264239555-en 
Organisation for Economic Co-operation and Development. (2016). Skills for a digital world (Policy Brief on the Future of Work). Paris, France: Author. Retrieved from http://www.oecd.org/els/emp/Skills-for-a-Digital-World.pdf

Park, J. (2013). All the ways of reading literature: Preservice English teachers' perspectives on disciplinary literacy. English Education, 45(4), 361-384. Retrieved from http://www.jstor.org/stable/24570980

Prensky, M. (2001). Digital natives, digital immigrants Part 1. On the Horizon, 9(5), 1-6. https://doi.org/10.1108/10748120110424816

Radovic, D., Black, L., Williams, J., \& Salas, C. E. (2018). Towards conceptual coherence in the research on mathematics learner identity: A systematic review of the literature. Educational Studies in Mathematics, 99(1), 21-42. https://doi.org/10.1007/978-3-319-77487-9 100017-1

Ragnedda, M. (2017). The third digital divide: A Weberian approach to digital inequalities. London, United Kingdom: Routledge. https://doi.org/10.4324/9781315606002

Rajala, A., Kumpulainen, K., Hilppö, J., Paananen, M., \& Lipponen, L. (2016). Connecting learning across school and out-of-school contexts. In O. Erstad, K. Kumpulainen, A. Mäkitalo, K.C. Schrøder, P. Pruulmann-Vengerfeldt, \& T. Jóhannsdóttir (Eds.), Learning across contexts in the knowledge society (pp. 15-35). Rotterdam, The Netherlands: Sense.

Reay, D., Crozier, G., \& Clayton, J. (2010). 'Fitting in' or 'standing out': Working-class students in UK higher education. British Educational Research Journal, 36(1), 107-124. https://doi.org/10.1080/01411920902878925

Ribble, M. (2015). Digital citizenship in schools: Nine elements all students should know. Arlington, OR: International Society for Technology in Education.

Rittenhofer, I. (2015). The reflexive case study method: A practice approach to SME globalization. International Journal of Entrepreneurial Behavior \& Research, 21(3), 410-418. https://doi.org/10.1108/IJEBR-12-2013-0215

Robertson, N. D. (2012). Content curation and the school librarian. Knowledge Quest, 41(2), E1-E5. Retrieved from http://www.ala.org/aasl/sites/ala.org.aasl/files/content/aaslpubsandjournals/knowledgequest/docs/KQ NovDec12 OE TAGS.pdf

Sangrá, A., Raffaghelli, J. E., \& Guitert-Catasús, M. (2019). Learning ecologies through a lens: Ontological, methodological and applicative issues. A systematic review of the literature. British Journal of Educational Technology, 50(4), 1619-1638. https://doi.org/10.1111/bjet.12795

Sefton-Green, J., \& Erstad, O. (2013). Identity, community and learning lives in the digital age. In O. Erstad \& J. Sefton-Green (Eds.), Identity, community and learning lives in the digital age (pp. 1-19). New York, Ny: Cambridge University Press.

Sefton-Green, J., \& Erstad, O. (2017). Researching 'learning lives'-A new agenda for learning, media and technology. Learning, Media and Technology, 42(2), 246-250. https://doi.org/10.1080/17439884.2016.1170034

Smagorinsky, P., Cook, L. S, \& Johnson, T. S. (2003). The twisting path of concept development in learning to teach. Teachers College Record, 105(8), 1399-1436. Retrieved from https://www.tcrecord.org/Content.asp?contentid=11552

Tsikriktsis, N. (2004). A technology readiness-based taxonomy of customers: A replication and extension. Journal of Service Research, 7(1), 42-52. https://doi.org/10.1177/1094670504266132

The University of Queensland. (2017-2018). Strengthening the gateways: Building pathways to success through active learning (Active Learning Pathways Project). Brisbane, Australia: Author. Retrieved from https://itali.uq.edu.au/about/projects/tig/alpp

Wenger, E. (1998). Communities of practice: Learning, meaning, and identity. Cambridge, United Kingdom: Cambridge University Press.

Williams, J. (2014). Teacher educator professional learning in the third space: Implications for identity and practice. Journal of Teacher Education, 65(4), 315-326. https://doi.org/10.1177/0022487114533128

Williams, M. \& Burden, R.L., (1997). Psychology for language teachers: A social constructivist approach. Cambridge, United Kingdom: Cambridge University Press.

Wise, J. B., \& O’Byrne, W. I. (2015). Social scholars: Educators' digital identity construction in open, online learning environments. Literacy Research: Theory, Method, and Practice, 64(1), 398-414. https://doi.org/10.1177/2381336915617607

Wortham, S. (2006). Learning identity: The joint emergence of social identification and academic learning. Cambridge, United Kingdom: Cambridge University Press. 
Corresponding author: Katherine McLay, k.mclay1@uq.edu.au

Copyright: Articles published in the Australasian Journal of Educational Technology (AJET) are available under Creative Commons Attribution Non-Commercial No Derivatives Licence (CC BY-NC-ND 4.0). Authors retain copyright in their work and grant AJET right of first publication under CC BY-NC-ND 4.0 .

Please cite as: McLay, K., \& Chua Reyes, V. (2019). Identity and digital equity: Reflections on a university educational technology course. Australasian Journal of Educational Technology, 35(6), 1529. https://doi.org/10.14742/ajet.5552 